\title{
Impaired Thymic Export and Apoptosis Contribute to Regulatory T-Cell Defects in Patients with Chronic Heart Failure
}

\author{
Ting-Ting Tang ${ }^{19}$, Zheng-Feng Zhu ${ }^{19}$, Jun Wang ${ }^{2}$, Wen-Cai Zhang ${ }^{1}$, Xin $\mathrm{Tu}^{3}$, Hong Xiao ${ }^{4}$, Xin-Ling $\mathrm{Du}^{1,5}$, \\ Jia-Hong Xia ${ }^{1,5}$, Nian-Guo Dong ${ }^{1,5}$, Wei Su ${ }^{1,5}$, Ni Xia ${ }^{1}$, Xing-Xing Yan ${ }^{1}$, Shao-Fang Nie ${ }^{1}$, Juan Liu', \\ Su-Feng Zhou ${ }^{1}$, Rui Yao ${ }^{1}$, Jiang-Jiao Xie ${ }^{1}$, Harish Jevallee ${ }^{1}$, Xiang Wang ${ }^{1}$, Meng-Yang Liao ${ }^{1}$, Guo-Ping \\ $\mathrm{Shi}^{6}$, Michael Fu', Yu-Hua Liao ${ }^{1}$, Xiang Cheng ${ }^{1 *}$ \\ 1 Laboratory of Cardiovascular Immunology, Key Laboratory of Biological Targeted Therapy of the Ministry of Education, Institute of Cardiology, Union Hospital, Tongji \\ Medical College of Huazhong University of Science and Technology, Wuhan, China, 2 Department of Cardiology, Yangzhou No. 1 People's Hospital, Yangzhou, China, \\ 3 Key Laboratory of Molecular Biophysics of the Ministry of Education, Cardio-X Institute, College of Life Science and Technology and Center of Human Genome Research, \\ Huazhong University of Science and Technology, Wuhan, China, 4 First Hospital of Wuhan, Wuhan, China, 5 Department of Cardiovascular Surgery, Union Hospital, Tongji \\ Medical College of Huazhong University of Science and Technology, Wuhan, China, 6 Department of Medicine, Brigham and Women's Hospital and Harvard Medical \\ School, Boston, Massachusetts, United States of America, 7 Department of Medicine, Sahlgrenska University Hospital, Gothenburg, Sweden
}

\begin{abstract}
Objective: Animal studies suggest that regulatory $\mathrm{T}\left(\mathrm{T}_{\text {reg }}\right)$ cells play a beneficial role in ventricular remodeling and our previous data have demonstrated defects of $\mathrm{T}_{\text {reg }}$ cells in patients with chronic heart failure (CHF). However, the mechanisms

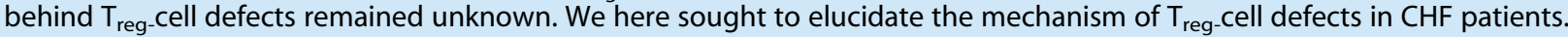

Methods and Results: We performed flow cytometry analysis and demonstrated reduced numbers of peripheral blood $\mathrm{CD}^{+} \mathrm{CD} 25^{+} \mathrm{FOXP3}^{+} \mathrm{CD}_{4} 5 \mathrm{RO}^{-} \mathrm{CD} 4 \mathrm{RA}^{+}$naïve $\mathrm{T}_{\text {reg }}\left(\mathrm{nT}_{\text {reg }}\right)$ cells and $\mathrm{CD}^{+} \mathrm{CD}^{2} 5^{+} \mathrm{FOXP} 3^{+} \mathrm{CD} 45 \mathrm{RO}^{+} \mathrm{CD} 45 \mathrm{RA}^{-}$memory $\mathrm{T}_{\text {reg }}$ $\left(\mathrm{mT}_{\text {reg }}\right)$ cells in CHF patients as compared with non-CHF controls. Moreover, the $\mathrm{nT}_{\text {reg }} / \mathrm{mT}_{\text {reg }}$ ratio $(p<0.01)$, $\mathrm{CD}^{+} \mathrm{CD} 25^{+} \mathrm{FOXP}^{+} \mathrm{CD} 4 \mathrm{RO}^{-} \mathrm{CD}^{-} 5 \mathrm{RA}^{+} \mathrm{CD} 31^{+}$recent thymic emigrant $\mathrm{T}_{\text {reg }}$ cell $\left(\mathrm{RTE}-\mathrm{T}_{\text {reg }}\right)$ frequency $(p<0.01)$, and T-cell receptor excision circle levels in $\mathrm{T}_{\text {reg }}$ cells $(p<0.01)$ were lower in CHF patients than in non-CHF controls. Combined annexin$V$ and 7-AAD staining showed that peripheral $T_{\text {reg }}$ cells from CHF patients exhibited increased spontaneous apoptosis and were more prone to interleukin (IL)-2 deprivation- and CD95 ligand-mediated apoptosis than those from non-CHF individuals. Furthermore, analyses by both flow cytometry and real-time polymerase chain reaction showed that $T_{\text {reg-cell }}$ frequency in the mediastinal lymph nodes or Foxp3 expression in hearts of CHF patients was no higher than that of the nonCHF controls.
\end{abstract}

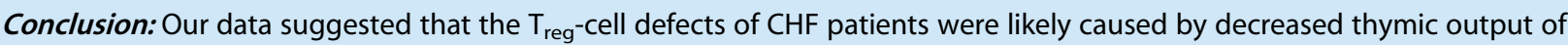
nascent $T_{\text {reg }}$ cells and increased susceptibility to apoptosis in the periphery.

Citation: Tang T-T, Zhu Z-F, Wang J, Zhang W-C, Tu X, et al. (2011) Impaired Thymic Export and Apoptosis Contribute to Regulatory T-Cell Defects in Patients with Chronic Heart Failure. PLoS ONE 6(9): e24272. doi:10.1371/journal.pone.0024272

Editor: Pierre Bobé, Institut Jacques Monod, France

Received March 31, 2011; Accepted August 4, 2011; Published September 15, 2011

Copyright: (c) 2011 Tang et al. This is an open-access article distributed under the terms of the Creative Commons Attribution License, which permits unrestricted use, distribution, and reproduction in any medium, provided the original author and source are credited.

Funding: This work was supported by grants from the National Natural Science Foundation of China (nos. 30600234 and 30871067 to XC; 81070106 to XT); the Program for New Century Excellent Talents in the University of China (NCET-09-0380 to XC); the National Basic Research Program of China (973 Program: 2007CB512000 and 2007CB5 12005 to YHL; 2012 CB517805 to YHL and XC); and the National Institutes of Health (USA) (HL60942, HL81090, and HL88547 to GPS). The funders had no role in study design, data collection and analysis, decision to publish, or preparation of the manuscript.

Competing Interests: The authors have declared that no competing interests exist.

*E-mail: nathancx@mail.hust.edu.cn

9 These authors contributed equally to this work.

\section{Introduction}

Chronic heart failure (CHF) is regarded as a state of chronic inflammation with elevated T-cell activation and inflammatory cytokine production in the circulatory system $[1,2]$. However, the pathogenic mechanisms responsible for this abnormal immune activation remain unknown. $\mathrm{T}_{\text {reg }}$ cells represent a unique lineage of $\mathrm{T}$ cells that play an essential role in the modulation of immune responses and the control of potentially harmful immune activations because of their immunoregulatory and immunosup- pressive characteristics [3]. Among the several types of $\mathrm{T}_{\text {reg }}$ cells that have been defined, one particular subset that constitutively expresses CD4, CD25 and the transcription factor Foxp3 has received much attention. Alterations in $\mathrm{CD} 4{ }^{+} \mathrm{CD} 25^{+} \mathrm{Foxp}^{+} \mathrm{T}_{\text {reg }^{-}}$ cell number or function is directly associated with the pathogenesis of several common human diseases, including acute coronary syndrome (ACS) [4,5], multiple sclerosis [6], type 1 diabetes [7], and rheumatoid arthritis [8]. Adoptive transfer of purified $\mathrm{T}_{\mathrm{reg}}$ cells suppresses immune injury and improves recovery in animal disease models [9-12]. 
Adverse ventricular remodeling occurs upon acute and chronic injury regardless of etiology, and it is related to poor prognosis of patients with heart failure [13]. There is compelling evidence that inflammatory mechanisms contribute to the process of adverse ventricular remodeling [14]. In animal models of heart failure, previous studies demonstrated that $\mathrm{T}_{\text {reg }}$ cells could be a target of heart failure therapeutics because CCR5-mediated $\mathrm{T}_{\text {reg-cell }}$ recruitment in the infarcted heart [15] and adoptively transferred $\mathrm{T}_{\text {reg }}$ cells [16] provided protection from adverse cardiac remodeling by preventing expansion of inflammation and fibrosis after adoptive transfer. In a previous publication, we found that circulating $\mathrm{T}_{\text {reg }}$ cells were reduced and their function was altered in CHF patients, regardless of etiology, suggesting that the defects in $\mathrm{T}_{\text {reg }}$ cells are responsible for the aberrant chronic immune activation in CHF patients [17]. It is believed that the understanding of mechanisms underlying $\mathrm{T}_{\text {reg }}$-cell defects in CHF patients is of great significance, especially with respect to

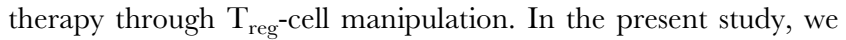
attempt to explore the mechanisms that might account for the $\mathrm{T}_{\text {reg }}$-cell defects in CHF patients by studying $\mathrm{T}_{\text {reg-cell production, }}$ survival, and tissue reallocation in these patients.

\section{Results}

\section{Reduced $n T_{\text {reg }}{ }^{-}, \mathrm{mT}_{\text {reg- }}$ and $R T E-T_{\text {reg }}$-cell frequency in CHF patients}

To determine the number of total $\mathrm{T}_{\text {reg }}$ cells and $\mathrm{T}_{\text {reg }}$ subsets, PBMCs were obtained from 52 CHF patients and 43 age-matched non-CHF controls followed by 6 -color flow cytometric analysis. Basic clinical characteristics of the study population are summarized in Table 1 . Within the naïve $\mathrm{CD}^{+} \mathrm{CD} 45 \mathrm{RA}^{+} \mathrm{CD} 45 \mathrm{RO}^{-}$ ( $\mathrm{R} 1$ in Figure 1A) or memory $\mathrm{CD} 4^{+} \mathrm{CD} 45 \mathrm{RA}^{-} \mathrm{CD} 45 \mathrm{RO}^{+}(\mathrm{R} 2$ in Figure 1A) $\mathrm{T}$ cells, a small subpopulation of cells with high expression of both CD25 and Foxp3 could be readily detected. $\mathrm{mT}_{\text {reg }}$ cells were characterized as $\mathrm{CD} 4^{+} \mathrm{CD} 25^{+} \mathrm{Foxp}^{+} \mathrm{CD}^{+} \mathrm{RA}{ }^{-}$ CD45 $\mathrm{RO}^{+}$cells $\left(\mathrm{R} 3\right.$ in Figure $1 \mathrm{~B}$, upper panel) and $\mathrm{nT}_{\text {reg }}$ cells were characterized as $\mathrm{CD} 4^{+} \mathrm{CD} 25^{+} \mathrm{Foxp}^{+} \mathrm{CD} 45 \mathrm{RA}^{+} \mathrm{CD} 45 \mathrm{RO}^{-}$ cells (R4 in Figure 1B, lower panel). $\mathrm{nT}_{\text {reg }}$ cells exhibited a lower expression of CD25 as compared with $\mathrm{mT}_{\text {reg }}$ cells (mean fluorescent intensity, MFI: $\mathrm{nT}_{\text {reg }}$ vs. $\mathrm{mT}_{\text {reg: }} 24.1 \pm 5.4$ vs. 54.6 $\pm 8.7, p<0.01)$. RTE- $\mathrm{T}_{\text {reg }}$ cells were identified as CD31 coexpressing $\mathrm{nT}_{\text {reg }}$ cells (Figure $1 \mathrm{G}$ ). The proportion of $\mathrm{T}_{\text {reg }}$ cells in total $\mathrm{CD}^{+} \mathrm{T}$ cells was significantly decreased in $\mathrm{CHF}$ patients when compared with non-CHF subjects (Figure 1D). The percentages of $\mathrm{nT}_{\text {reg }}$ and $\mathrm{mT}_{\text {reg }}$ cells within $\mathrm{CD}^{+} \mathrm{T}$ cells were also significantly lower in CHF patients than in age-matched nonCHF subjects (non-CHF vs. CHF patients: $\mathrm{nT}_{\text {reg: }}: 1.17 \pm 0.41 \%$ vs. $0.59 \pm 0.31 \%, p<0.01 ; \mathrm{mT}_{\text {reg }}: 3.27 \pm 0.92 \%$ vs. $2.02 \pm 0.65 \%$, $p<0.01$; Figure 1D). CHF patients showed a significantly lower $\mathrm{nT}_{\text {reg }} / \mathrm{mT}_{\text {reg }}$ ratio (non-CHF vs. CHF patients: $36 \pm 10 \%$ vs. $30 \pm 12 \%, p<0.05$; Figure 1E). Furthermore, we observed that proportions of RTE- $\mathrm{T}_{\text {reg }}$ cells in the total $\mathrm{T}_{\text {reg-cell population in }}$ $\mathrm{CHF}$ patients were significantly reduced when compared to agematched, non-CHF controls, suggesting that thymic production of $\mathrm{T}_{\text {reg }}$ cells was impaired in CHF patients (non-CHF vs. CHF: $4.97 \pm .34 \%$ vs. $3.00 \pm 0.97 \%, p<0.01$; Figure $1 \mathrm{~F}$ ). However, no difference in total $\mathrm{T}_{\text {reg }}, \mathrm{nT}_{\text {reg }}, \mathrm{mT}_{\text {reg }}$, and $\mathrm{RTE}-\mathrm{T}_{\text {reg }}$ cells between IHF or NIHF patients was observed (Figure 1D-F). Similar results were obtained when we compared the absolute numbers of total $\mathrm{T}_{\text {reg }}, \mathrm{nT}_{\text {reg }}, \mathrm{mT}_{\text {reg }}$, and RTE- $\mathrm{T}_{\text {reg }}$ cells between CHF patients and non-CHF controls (Table 2).

Consistent with our previous report [17], we observed that total $\mathrm{T}_{\text {reg }}$ number was negatively correlated with NT-proBNP in CHF patients. Furthermore, the present study also found that NT-
proBNP and $\mathrm{nT}_{\text {reg }}$ or $\mathrm{mT}_{\text {reg }}$ numbers were negatively correlated (Table 3).

\section{Decreased intracellular TREC levels in $T_{\text {reg }}$ cells from CHF patients}

TREC is a marker for nascent thymic T cells [18]. We studied intracellular levels of TRECs in $\mathrm{T}_{\text {reg }}$ cells isolated from $25 \mathrm{CHF}$ patients and 15 age-matched non-CHF subjects using quantitative real-time PCR. Flow cytometry was used to determine the purity of $\mathrm{T}_{\text {reg }}$ cells after cell sorting (Figure 2A, left panel). The TREC content in $\mathrm{T}_{\text {reg }}$ cells was significantly lower in CHF than that in non-CHF patients (non-CHF vs. CHF patients: $1.38 \pm 0.49 \times 10^{3}$ / $10^{6}$ cells vs. $0.60 \pm 0.32 \times 10^{3} / 10^{6}$ cells, $p<0.01$; Figure $2 \mathrm{~A}$, right panel). There was no significant difference in $\mathrm{T}_{\text {reg-cell }}$ TREC content between IHF and NIHF patients. Spearman's correlation test revealed a positive association between $\mathrm{T}_{\text {reg-cell TREC level }}$ and RTE- $\mathrm{T}_{\text {reg }}$ cell proportion in both $\mathrm{CHF}$ patients and non-CHF controls $(\mathrm{r}=0.75, p<0.001$; Figure 2B).

\section{Increased spontaneous and IL-2 deprivation/Fas- mediated apoptosis in $\mathrm{T}_{\text {reg }}$ cells from CHF patients}

Increased apoptosis and decreased survival could be a

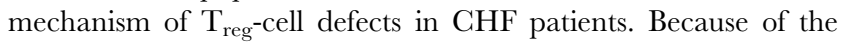
fixation and permeabilization procedures used for detecting $\mathrm{T}_{\text {reg }}$ cells using Foxp3 antibodies by FACS, we detected apoptotic $\mathrm{T}_{\text {reg }}$ cells with antibodies against CD127, a newly identified $\mathrm{T}_{\text {reg }}$ surface marker that correlates well with Foxp3 [19]. In both CHF patients and non-CHF controls, CD $4^{+} \mathrm{CD} 25^{+} \mathrm{Foxp}^{+} \mathrm{T}_{\text {reg }}$ cells were correlated with $\mathrm{CD} 4^{+} \mathrm{CD} 25^{+} \mathrm{CD} 127^{\text {low } /-} \mathrm{T}_{\text {reg }}$ cells $(\mathrm{r}=0.91$, $p<0.001$, Figure 3$)$. When we gated the $\mathrm{CD} 4^{+} \mathrm{CD} 25^{+} \mathrm{CD} 127^{\text {low } /-}$ cells, we found that when this cell population was derived from CHF patients, irrespective of the etiology, there was a significantly higher percentage of apoptotic annexin $\mathrm{V}^{+} 7-\mathrm{AAD}^{-}$cells than when derived from non-CHF controls (non-CHF vs. CHF patients: $8.79 \pm 3.37 \%$ vs. $14.78 \pm 4.08 \%, p<0.01$; Figure $4 \mathrm{~A}$ ).

Enhanced apoptosis often correlates with altered expression of apoptosis-associated genes. We compared the levels of antiapoptotic gene $\mathrm{Bcl}-2$ and pro-apoptotic gene Bak expression between $\mathrm{CD} 4^{+} \mathrm{CD} 25^{+} \mathrm{CD} 127^{\text {low/ }}-\mathrm{T}_{\text {reg }}$ cells isolated from $\mathrm{CHF}$ patients and non-CHF controls. Significantly lower Bcl-2 expression $(p<0.01)$ and higher Bak expression $(p<0.01)$ were observed in $\mathrm{T}_{\text {reg }}$ cells from $\mathrm{CHF}$ patients when compared with those from non-CHF controls (Figure 4B).

IL-2 is essential for the development, function and homeostasis of $\mathrm{T}_{\text {reg }}$ cells [20]. However, human $\mathrm{T}_{\text {reg }}$ cells do not produce this cytokine and therefore are susceptible to IL-2 deprivation, which

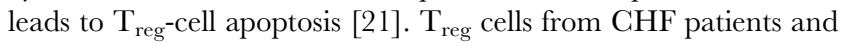
non-CHF controls might exhibit different susceptibilities to IL-2 deprivation. To test this hypothesis, we incubated $\mathrm{T}_{\text {reg }}$ cells from the different patient populations with anti-human IL-2 monoclonal antibodies for 3 days. $\mathrm{T}_{\text {reg }}$ cells from $\mathrm{CHF}$ patients were more sensitive to IL-2 deprivation-induced apoptosis when compared with $\mathrm{T}_{\text {reg }}$ cells from non-CHF subjects (non-CHF vs. CHF: $22.35 \pm 4.12 \%$ vs. $33.26 \pm 5.89 \%, p<0.01$; Figure $5 \mathrm{~A}$ ).

$\mathrm{T}_{\text {reg-cell apoptosis could also be induced by the interactions }}$ between death receptor CD95 with the CD95 ligand (CD95L) [22]. Human $\mathrm{T}_{\text {reg }}$ cells constitutively express these death receptors and are thus highly sensitive to CD95-CD95L-mediated apoptosis [23]. Increased apoptosis in $\mathrm{T}_{\text {reg }}$ cells from CHF patients suggests that $\mathrm{T}_{\text {reg }}$ cells from these patients express high levels of CD95 and/or are more sensitive to CD95L. To test this hypothesis, we compared the expression level of CD95 and sensitivity toward CD95L-triggered apoptosis in $\mathrm{T}_{\text {reg }}$ cells from $\mathrm{CHF}$ patients and 
Table 1. Clinical characteristics of study population.

\begin{tabular}{lllll}
\hline & & & & \\
\hline & CHF patients $(\mathbf{n}=\mathbf{5 2})$ & NIHF patients $(\mathbf{n}=\mathbf{3 2})$ & IHF patients (n=20) & $\begin{array}{l}\text { Non-CHF controls } \\
(\mathbf{n}=\mathbf{4 3})\end{array}$ \\
\hline Age (year) & $44 \pm 13$ & $40 \pm 14$ & $51 \pm 8$ & $42 \pm 12$ \\
Gender (Male/Female) & $31 / 21$ & $17 / 15$ & $14 / 6$ & $28 / 15$ \\
NYHA (II/III/V) & $25 / 21 / 6$ & $12 / 16 / 4$ & $13 / 5 / 2$ & - \\
LVEF (\%) & $35.38 \pm 6.24$ & $35.06 \pm 6.41$ & $35.9 \pm 6.09$ & - \\
LVEDD (cm) & $6.11 \pm 0.47$ & $6.16 \pm 0.5$ & $6.02 \pm 0.41$ & 0 \\
Hypertension (\%) & 37 & 16 & 70 & - \\
NT-proBNP (pg/ml) & $2955.52 \pm 1971.55$ & $2756.33 \pm 1628.37$ & $3176.8 \pm 2442.88$ & 0 \\
Medication (\%) & & & & 0 \\
ACEI/ARBs & 90 & 91 & 90 & 0 \\
Antisterone & 42 & 47 & 35 & 0 \\
Digitalis & 31 & 28 & 35 & 0 \\
$\beta$-Blocker & 87 & 88 & 85 & 80 \\
Diuretics & 73 & 50 & & - \\
\hline
\end{tabular}

Data is presented as mean \pm SD, or number or percentage of patients or healthy controls (HCs). NIHF: non-ischemic heart failure; IHF: ischemic heart failure; NYHA, New York Heart Association; LVEF, left ventricular ejection fraction; LVEDD, left ventricular end-diastolic dimension; NT-ProBNP, N-terminal Pro B-type natriuretic peptide; ACEl, angiotensin-converting enzyme inhibitor; ARB, angiotensin receptor blocker.

doi:10.1371/journal.pone.0024272.t001

non-CHF controls. CD95 expression on $\mathrm{T}_{\text {reg }}$ cells from CHF patients was significantly higher than on $\mathrm{T}_{\text {reg }}$ cells from non-CHF controls (non-CHF vs. CHF: $73.78 \pm 8.12 \%$ vs. $84.30 \pm 6.67 \%$, $p<0.01$; Figure 5B). CD95L induced apoptosis of $\mathrm{T}_{\text {reg }}$ cells from CHF patients in a dose- and time-dependent manner (Figure 5C).

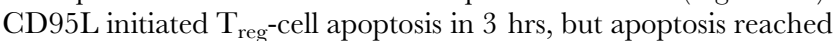
a peak after $12 \mathrm{hrs}$ of induction. When incubated with $100 \mathrm{ng} / \mathrm{ml}$ of CD95L for $12 \mathrm{hrs}, \mathrm{T}_{\text {reg }}$ cells prepared from CHF patients showed higher percentages of cells undergoing CD95L-induced apoptosis than in non-CHF subjects (non-CHF vs. CHF patients: $19.43 \pm 6.87 \%$ vs. $36.52 \pm 12.03 \%, p<0.01$; Figure 5D). These observations could explain the increased $\mathrm{T}_{\text {reg-cell apoptosis in }}$ CHF patients (Figure 4A). Furthermore, we detected significantly higher plasma levels of soluble CD95L in CHF patients than in non-CHF controls (non-CHF vs. CHF patients: $77.28 \pm 5.26 \%$ vs. $101.22 \pm 5.06 \%, p<0.01$; Figure 5E). Among the CHF subgroups IHF and NIHF, we did not detect any differences in either IL-2 deprivation- or CD95-mediated $\mathrm{T}_{\text {reg-cell apoptosis (Figure } 5 \mathrm{~A} /}$ 5D). Plasma CD95L levels were also similar between CHF, IHF, and NIHF patients (Figure 5E). Taken together, these findings suggest that $\mathrm{T}_{\text {reg }}$ cells from CHF patients were more prone to apoptosis and that IL-2 and CD95/CD95L might be involved in regulation of $\mathrm{T}_{\text {reg-cell survival. }}$

\section{4. $T_{\text {reg }}$ cells accumulate neither in mediastinal lymph nodes nor in failing hearts}

One possible explanation for reduced $\mathrm{T}_{\text {reg }}$-cell number in CHF patients is the reallocation of these cells to the lymph nodes or disease-affected organs. We compared the proportion of $\mathrm{CD} 4^{+} \mathrm{CD} 25^{+} \mathrm{Foxp}^{+} \mathrm{T}_{\text {reg }}$ cells to total $\mathrm{CD} 4^{+} \mathrm{T}$ cells in the mediastinal lymph nodes from $\mathrm{CHF}$ patients and non-CHF controls. Mediastinal lymph node $\mathrm{T}_{\text {reg }}$ cells from $\mathrm{CHF}$ patients were significantly fewer than from non-CHF controls (Figure 6A/ 6B). Total lymphocyte Foxp3 mRNA levels were also significantly lower in CHF, IHF and NIHF patients than in non-CHF controls (Figure 6C). To examine whether $\mathrm{T}_{\text {reg }}$ cell accumulation in the heart was different between $\mathrm{CHF}$ and non-CHF controls, Foxp3 RT-PGR was performed on biopsied cardiac samples. No difference was found between failing hearts and hearts from donors, although Foxp3 levels were low in all tested heart samples (Figure 6C).

\section{Discussion}

As the final common pathway of many cardiovascular diseases, $\mathrm{CHF}$ is a complex multi-step disorder and several mechanisms participate in its pathogenesis. There is compelling evidence that inflammation and autoimmune abnormalities play an important role in the progression of heart failure [1,24,25]. Various autoantibodies, which are directed against different cardiac antigens, such as cardiac myosin, cardiac troponin I, cardiolipin, beta $_{1}$-adrenergic and M2 muscarinic receptors can be detected in the serum of patients with NIHF or IHF [26-29]. These autoantibodies can lead to cardiac injury, and they correlate with the deterioration of cardiac function. Other autoimmune abnormalities include infiltration of $\mathrm{T}$ cells in endomyocardial biopsies from patients with idiopathic dilated cardiomyopathy (DCM). Additionally, the transfer of peripheral blood lymphocytes from DCM patients to severe combined immunodeficiency (SCID) mice leads to ventricular remodeling [30]. In animal models, lymphocytes from rats with IHF can recognize and kill normal neonatal rat cardiac myocytes in vitro [31] and lead to autoimmune myocarditis in vivo after adoptive transfer [32].

$\mathrm{T}_{\text {reg }}$ cells play a key role in the control of inflammation and autoimmune responses, and altered $\mathrm{T}_{\text {reg }}$ cells predispose patients for uncontrolled immune activation or autoimmunity [3]. CHF patients were previously reported to have impaired $\mathrm{T}_{\text {reg-cell }}$ number and function, but the precise mechanism behind this defect remains largely unknown [17]. In this study, we showed that reduced $\mathrm{T}_{\text {reg }}$ cell number and function in $\mathrm{CHF}$ patients might be explained by impaired $\mathrm{T}_{\text {reg-cell thymic output and increased }}$ apoptosis of these cell populations.

Like other $\mathrm{T}$ cells, $\mathrm{T}_{\text {reg }}$ cells develop in the thymus [33]. A small fraction of $\mathrm{T}_{\text {reg }}$ cells with a naïve $\mathrm{CD} 45 \mathrm{RA}^{+} \mathrm{CD} 45 \mathrm{RO}^{-}$surface profile $\left(\mathrm{nT}_{\text {reg }}\right)$ has recently been detected in the circulation. However, this $\mathrm{nT}_{\text {reg }}$ subset declines with age, as does thymic 


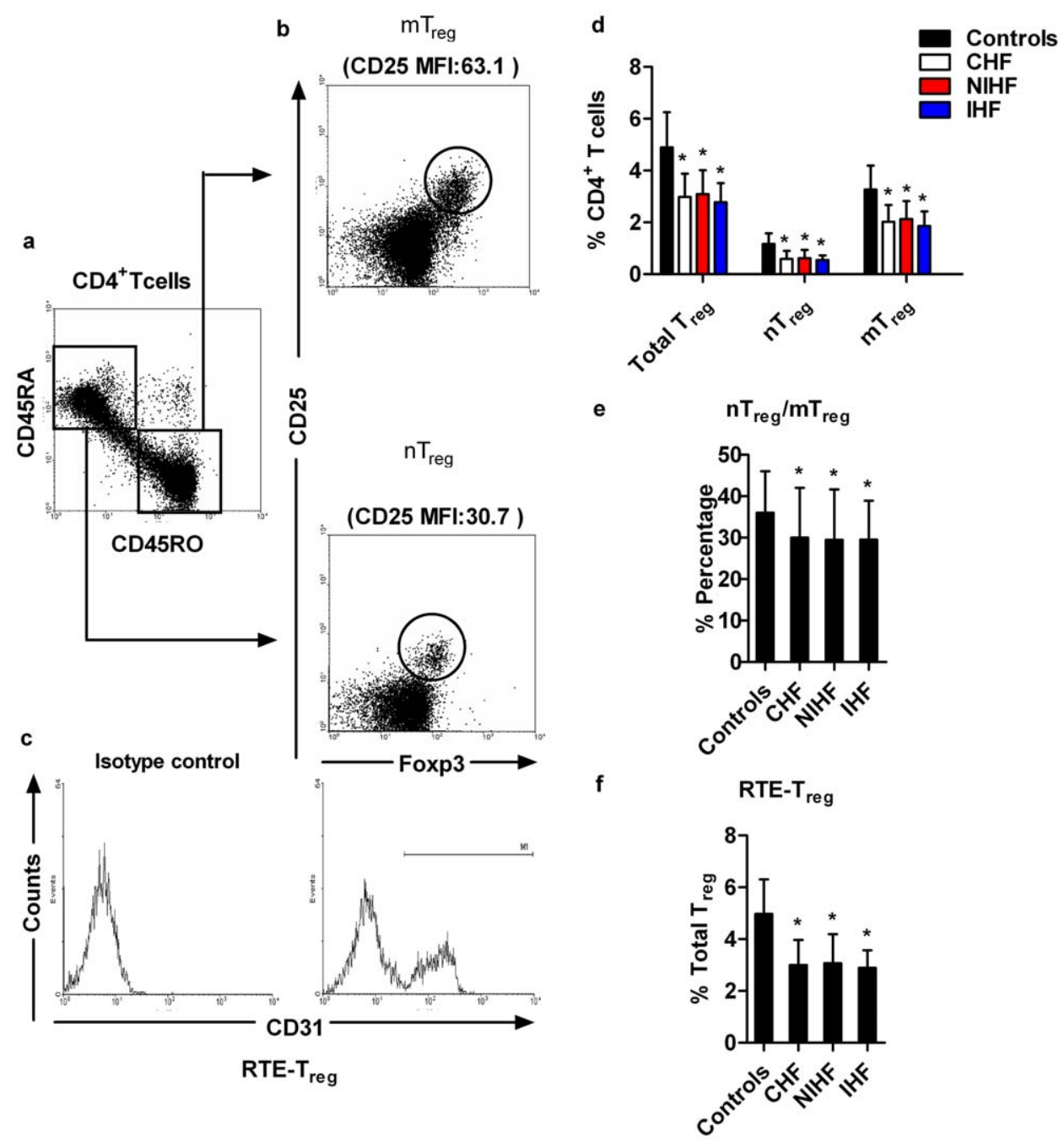

Figure 1. Frequencies of the regulatory $\mathbf{T}\left(\mathbf{T}_{\text {reg }}\right)$-cell subset in CHF patients and non-CHF controls. PBMCs of CHF patients $(n=52,32$ $\mathrm{NIHF}$ and $20 \mathrm{IHF}$ ) and non-CHF controls $(n=43)$ were included, and a 6-color flow cytometric analysis using mAbs specific for CD4, CD25, CD45RA, CD45RO, CD31 and Foxp3 was performed. a. Representative FACS images from a non-CHF control. Dot plots show CD45RA and CD45RO expression on gated $C D 4^{+} T$ cells. Naïve and memory $C D 4^{+} T$ cells were defined as $C D 45 R A^{+} C D 45 R O^{-}(R 1)$ and $C D 45 R A^{-} C D 45 R O^{+}(R 2)$, respectively. b. A small subpopulation of memory $T_{\text {reg }}\left(\mathrm{mT}_{\text {reg }}\right)$ (upper panel) and naïve $\mathrm{T}_{\text {reg }}\left(\mathrm{nT}_{\text {reg }}\right.$ ) (lower panel) cells expressing both CD25 and Foxp3 was detectable. c. Histograms show the expression of CD31 on $\mathrm{nT}_{\text {reg }}$ cells. Recent thymic export- $\mathrm{T}_{\text {reg }}\left(\mathrm{RTE}-\mathrm{T}_{\text {reg }}\right.$ ) cells were identified as $\mathrm{CD} 4^{+} \mathrm{CD} 25^{+} \mathrm{Foxp} 3^{+} \mathrm{CD} 45 \mathrm{RA} \mathrm{A}^{+} \mathrm{C}-$ $\mathrm{D}_{5} \mathrm{RO}^{-} \mathrm{CD}^{+} 1^{+}$cells. d. Frequencies of total $\mathrm{T}_{\text {reg, }}, \mathrm{nT}_{\text {reg, }}$ and $\mathrm{mT}_{\text {reg }}$ cells in different patient populations were determined as percentages of total CD4 ${ }^{+}$ $\mathrm{T}$ cells. e. The ratio of $\mathrm{nT}_{\text {reg }}$ to $\mathrm{mT}_{\text {reg }}$ cells in different subject populations. $\mathrm{f}$. RTE- $\mathrm{T}_{\text {reg }}$ cell frequency in different subject populations was presented as a percentage of total $\mathrm{T}_{\text {reg }}$ cells. ${ }^{*} p<0.05$ vs. non-CHF controls. doi:10.1371/journal.pone.0024272.g001

output and other naïve $\mathrm{T}$ cells [34]. By contrast, the majority of circulating $\mathrm{T}_{\text {reg }}$ cells appear as a mature population with a memory CD45RA ${ }^{-} \mathrm{CD} 45 \mathrm{RO}^{+}$phenotype; these $\mathrm{mT}_{\text {reg }}$ cells are stable throughout the life span, and the levels of $\mathrm{mT}_{\text {reg }}$ cells increase during aging [35,36]. $\mathrm{nT}_{\text {reg }}$ cells could represent the de novo generation of thymic lymphocytes, so the assessment of $\mathrm{nT}_{\text {reg }}$

Table 2. Absolute number of $\mathrm{T}_{\text {reg }}, \mathrm{nT}_{\text {reg }}, \mathrm{mT}_{\text {reg }}$ and $\mathrm{RTE}-\mathrm{T}_{\text {reg }}$ in the study population.

\begin{tabular}{|c|c|c|c|c|c|}
\hline & CD4 $^{+} T$ cells $\left(10^{6} / \mathrm{L}\right)$ & $T_{\text {reg }}\left(10^{6} / \mathrm{L}\right)$ & $n T_{\text {reg }}\left(10^{6} / L\right)$ & $\mathrm{mT}_{\text {reg }}\left(10^{6} / \mathrm{L}\right)$ & RTE-T ${ }_{\text {reg }}\left(10^{6} / \mathrm{L}\right)$ \\
\hline CHF patients $(n=52)$ & $341.95 \pm 206.28$ & $9.92 \pm 5.78^{*}$ & $1.92 \pm 1.24^{*}$ & $6.84 \pm 4.30^{*}$ & $0.31 \pm 0.24^{*}$ \\
\hline NIHF patients $(n=32)$ & $346.55 \pm 205.81$ & $10.52 \pm 6.26^{*}$ & $2.06 \pm 1.37^{*}$ & $7.38 \pm 4.81^{*}$ & $0.35 \pm 0.29^{*}$ \\
\hline $\begin{array}{l}\text { IHF patients } \\
(n=20)\end{array}$ & $334.60 \pm 212.16$ & $8.96 \pm 4.92^{*}$ & $1.69 \pm 0.97^{*}$ & $5.97 \pm 3.27^{*}$ & $0.25 \pm 0.13^{*}$ \\
\hline Non-CHF controls $(n=43)$ & $289.99 \pm 155.36$ & $13.96 \pm 7.6$ & $3.33 \pm 2.07$ & $9.51 \pm 5.49$ & $0.70 \pm 0.43$ \\
\hline
\end{tabular}

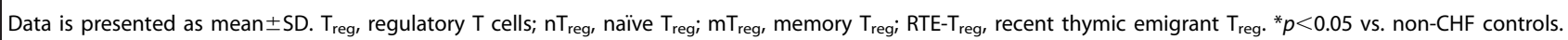
doi:10.1371/journal.pone.0024272.t002 
Table 3. Correlation analysis between $T_{\text {reg }}$ or its subset frequency and NT-proBNP in CHF patients.

\begin{tabular}{llll}
\hline & \multicolumn{3}{l}{} \\
& $\mathbf{N T}$-proBNP & \\
\cline { 2 - 4 } & $\mathbf{T}_{\text {reg }}$ & $\mathbf{n T}_{\text {reg }}$ & $\mathbf{m T}_{\text {reg }}$ \\
\hline Coefficients & -0.589 & -0.557 & -0.446 \\
$p$ values & $<0.01$ & $<0.01$ & $<0.01$ \\
\hline
\end{tabular}

NT-proBNP, N-terminal Pro B-type natriuretic peptide; $\mathrm{T}_{\text {reg, }}$ regulatory $\mathrm{T}$ cells; $\mathrm{nT}_{\text {reg, }}$ naïve $\mathrm{T}_{\text {reg; }} ; \mathrm{mT}_{\text {reg, }}$, memory $\mathrm{T}_{\text {reg. }}$.

doi:10.1371/journal.pone.0024272.t003

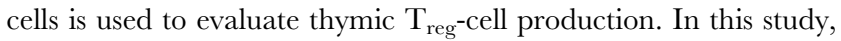
we provided evidence that, in addition to decreased percentages of $\mathrm{nT}_{\text {reg }}$ and $\mathrm{mT}_{\text {reg }}$ cells, a shift from $\mathrm{nT}_{\text {reg }}$ cells toward $\mathrm{mT}_{\text {reg }}$ cells was evidenced by a reduced $\mathrm{nT}_{\text {reg }} / \mathrm{mT}_{\text {reg }}$ cell ratio in $\mathrm{CHF}$ patients. This result indicated the possibility that impaired thymic export contributes to $\mathrm{T}_{\text {reg }}$ cell defects in this patient population. However, $\mathrm{nT}_{\text {reg }}$ cells can proliferate after thymic output while retaining their naïve phenotype [37]. CD31 has been used as a direct marker of thymic output and enabled the discrimination of recent thymic emigrant (RTE) $\mathrm{T}_{\text {reg }}$ cells from peripherally expanded $\mathrm{nT}_{\text {reg }}$ cells [38]. Thus, the assessment of $\mathrm{nT}_{\text {reg }}$ cells co-expressing CD31 (RTE-T reg$_{\text {) }}$ is now used to evaluate the thymic output of $T_{\text {reg }}$ cells. The significant reduction of peripheral RTE- $\mathrm{T}_{\text {reg }}$ cell content in CHF patients, when compared to the non-CHF controls, suggests a reduction of thymic $\mathrm{T}_{\text {reg }}$-cell output during the development of heart failure. An alternative approach

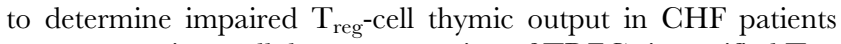
was to assess intracellular concentration of TRECs in purified $\mathrm{T}_{\text {reg }}$ cells. TRECis are generated during the process of T-cell receptor rearrangement in $\mathrm{T}$-cell differentiation and do not duplicate during mitosis. TRECs are diluted out during homeostatic or antigen-driven T-cell proliferation in the periphery [18]. Therefore, TRECs are enriched in the newly synthesized and exported T-cell pool. $\mathrm{nT}_{\text {reg }}$ cells, especially RTE- $\mathrm{T}_{\text {reg }}$ cells, have higher frequencies of TRECs as compared with $\mathrm{mT}_{\text {reg }}$ cells [38]. TREG content reduction in total $\mathrm{T}_{\text {reg }}$ cells from CHF patients further supported our hypothesis that the Treg-cell output in the thymus of a CHF patient is functionally altered. Hass et al. recently reported that $T_{\text {reg }}$ cells from patients with and without multiple sclerosis showed different activities in suppressing T-effector cells. However, such differences disappeared after depleting the RTE$\mathrm{T}_{\text {reg }}$ cells, indicating a crucial role of $\mathrm{RTE}-\mathrm{T}_{\text {reg }}$ cells in the functional properties of the entire $\mathrm{T}_{\text {reg }}$ population [38]. Thus, impaired thymus export of $\mathrm{T}_{\text {reg }}$ cells could be associated not only with the number but also with the functional defect of $\mathrm{T}_{\text {reg }}$ cells in CHF patients. Over the course of multiple sclerosis, for example, patients appear capable of amplifying $\mathrm{mT}_{\text {reg }}$-cell subpopulations to compensate for impaired thymic production of $\mathrm{T}_{\text {reg }}$ cells [39]. In the case of $\mathrm{CHF}$, in contrast, the homeostatic control of $\mathrm{T}_{\text {reg }}$ cells seems to be disturbed. Both $\mathrm{nT}_{\text {reg }}$ and $\mathrm{mT}_{\text {reg }}$ cells were reduced in CHF patients (Figure 1D).

The homeostasis of $\mathrm{T}_{\text {reg }}$ cells is maintained by a balance between $\mathrm{T}_{\text {reg-cell generation and depletion. Apoptosis-induced }}$ alteration of $\mathrm{T}_{\text {reg-cell levels has been associated with several }}$ diseases. For example, intrathyroidal $\mathrm{CD} 4^{+} \mathrm{CD} 25^{+} \mathrm{T}_{\text {reg }}$ cells from patients with autoimmune thyroid diseases were prone to apoptosis, which led to a local $\mathrm{T}_{\text {reg-cell reduction [40]. In }}$ contrast, patients with metastatic epithelial cancer demonstrated a significantly elevated proportion of peripheral $\mathrm{T}_{\text {reg }}$ cells, and these cells were protected from apoptosis [41]. Apoptosis not only a
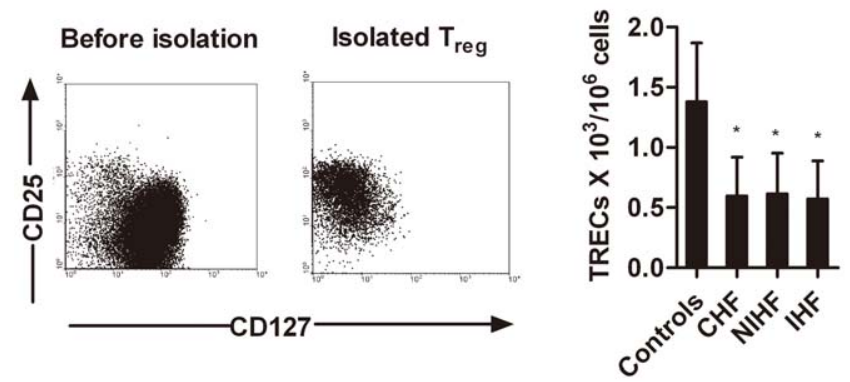

b

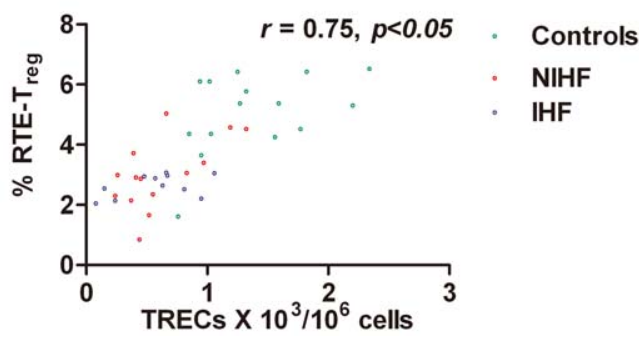

Figure 2, Analysis of intracellular T-cell receptor excision circle (TREC) levels in purified $T_{\text {reg }}$ cells from CHF patients and nonCHF controls. a. $\mathrm{CD} 4^{+} \mathrm{CD} 25^{+} \mathrm{CD} 127^{\text {low }} \mathrm{T}_{\text {reg }}$ cells from $\mathrm{CHF}$ patients $(n=25,14$ NIHF and 11 IHF) and non-CHF controls $(n=15)$ were isolated by magnetic selection (left), and the TREC levels were determined by RT-PCR (right; ${ }^{*} p<0.01$ ) and compared to non-CHF controls. b. RTE-Treg frequencies were plotted against TREC levels in purified $T_{\text {reg }}$ cells from CHF patients and non-CHF controls $(r=0.75, p<0.001)$.

doi:10.1371/journal.pone.0024272.g002

reduces the number of $T_{\text {reg }}$ cells, but also reduces their functions. By using $\mathrm{T}$-effector cell suppression assays, $\mathrm{T}_{\text {reg-cell apoptosis was }}$ closely associated with their capacity to inhibit T-effector cell proliferation [42]. In patients with type 1 diabetes, an increase in apoptosis was correlated with a decline in the suppressive potential of $\mathrm{T}_{\text {reg }}$ cells [43]. As suggested by these studies, high sensitivity to IL-2 deprivation or FasL-induced apoptosis may contribute in part to the defect of $\mathrm{T}_{\text {reg }}$ cells in CHF patients. $\mathrm{T}_{\text {reg }}$ cells from $\mathrm{CHF}$ patients were more susceptible to apoptosis following IL-2 deprivation. Upon antigen activation, $T$ cells induce the expression of CD95, a member of the tumor necrosis factor receptor/nerve growth factor receptor superfamily that induces apoptosis by binding to CD95L and subsequently activating

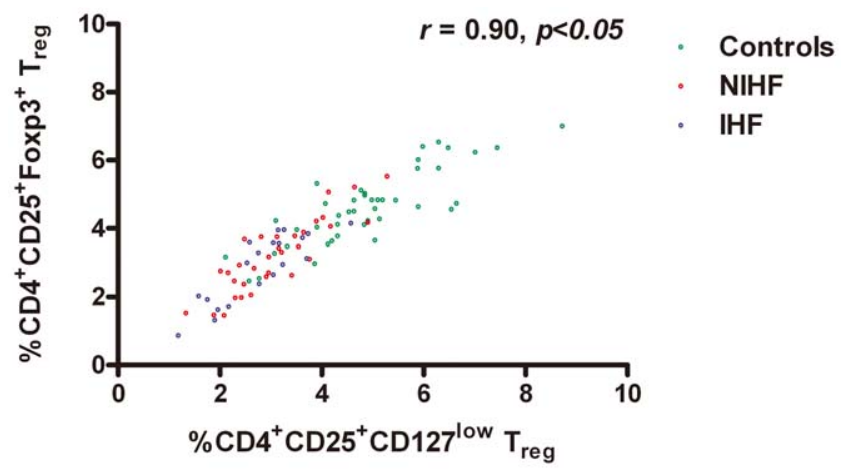

Figure 3. Correlation between $\mathrm{CD}^{+} \mathrm{CD} 25^{+} \mathrm{Foxp}^{+} \mathrm{T}_{\text {reg }}$ cells and $\mathrm{CD4}^{+} \mathrm{CD25} 5^{+} \mathrm{CD} 127^{\text {low }} \mathbf{T}_{\text {reg }}$ cells. Frequencies of $\mathrm{CD} 4^{+} \mathrm{CD} 25^{+} \mathrm{Foxp} 3^{+}$ $\mathrm{T}_{\text {reg }}$ cells were plotted against $\mathrm{CD} 4^{+} \mathrm{CD} 25^{+} \mathrm{CD} 127^{\text {low }} \mathrm{T}_{\text {reg }}$ cells in $47 \mathrm{CHF}$ patients and 38 non-CHF controls $(r=0.91, p<0.001)$.

doi:10.1371/journal.pone.0024272.g003 
a
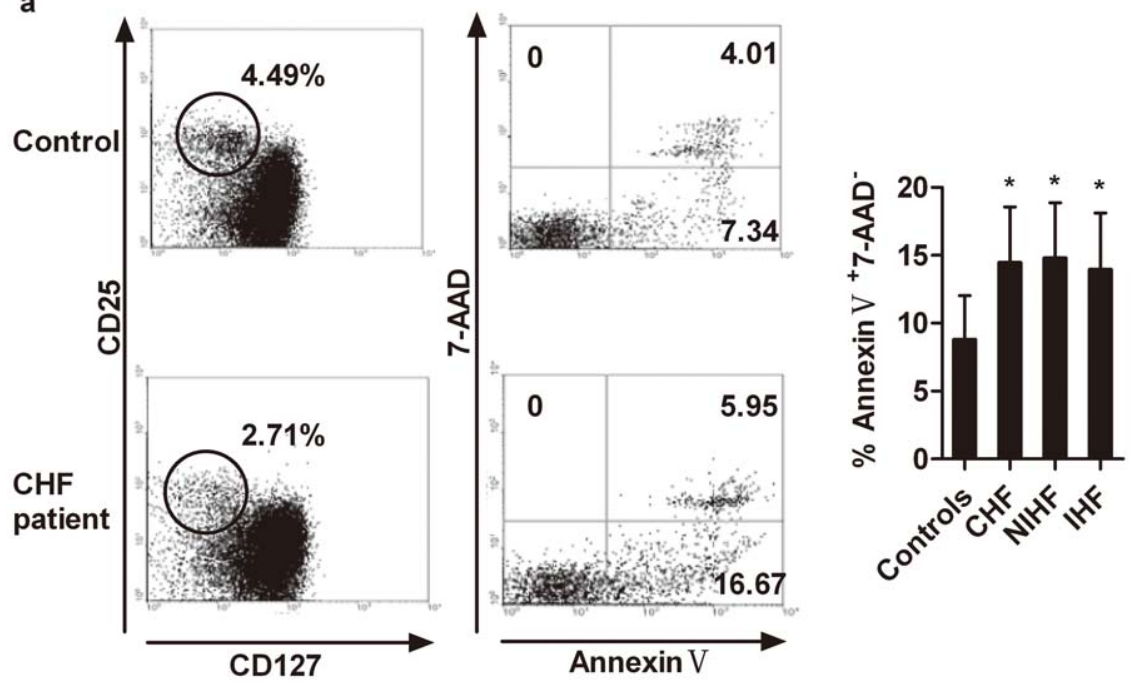

b

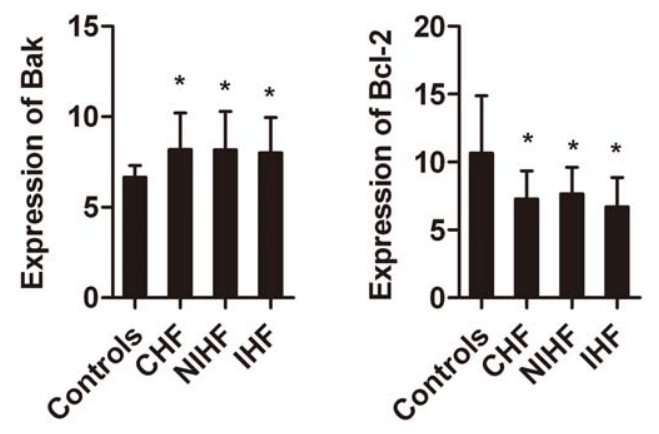

Figure 4. Spontaneous apoptosis of $\mathbf{T}_{\text {reg }}$ cells from CHF patients and non-CHF controls. PBMCs of 47 CHF patients and 38 non-CHF controls were stained with anti-CD4, anti-CD25, anti-CD127, annexin-V and 7-AAD and analyzed by flow cytometry. a. Representative FACS analyses from one non-CHF control and one CHF patient are shown. A small subpopulation of $C D 25^{+} C D 127^{\text {low } /-}$ cells were gated and identified as $T_{\text {reg }}$ cells (left panels). The staining of annexin-V and 7-AAD was further analyzed on gated $\mathrm{T}_{\text {reg }}$ cells (middle), and apoptosis levels of the $\mathrm{T}_{\text {reg }}$ cells are calculated as percentage of annexin- $\mathrm{V}^{+} 7-\mathrm{AAD}^{-}$cells among $7-\mathrm{AAD}^{-}$cells (right; ${ }^{*} p<0.01$ vs. non-CHF controls). b. $\mathrm{CD}^{+} \mathrm{CD} 25^{+} \mathrm{CD} 127^{\text {low } /{ }^{-}} \mathrm{T}_{\text {reg }}$ cells from CHF patients ( $n=25,14$ NIHF and 11 IHF) and non-CHF controls $(n=15)$ were isolated by magnetic selection (left), and the expression of both the anti-apoptotic gene Bcl-2 (top panel) and the pro-apoptotic gene Bak (bottom panel) was measured. ${ }^{*} p<0.05$ vs. non-CHF controls. doi:10.1371/journal.pone.0024272.g004

caspase [44]. In the present study, we demonstrated that $\mathrm{T}_{\text {reg }}$ cells in CHF patients had higher CD95 expression levels and were more sensitive to CD95/CD95L-mediated apoptosis than those in non-CHF subjects. Indeed, we also detected concurrent increases in serum soluble CD95L levels in CHF patients, consistent with prior observations [45]. These findings strongly suggest that the CD95/CD95L pathway is an important regulator of $\mathrm{T}_{\text {reg-cell }}$ apoptosis in $\mathrm{CHF}$ patients.

After release from the thymus, $\mathrm{T}_{\text {reg }}$ cells circulate continuously from blood to lymphoid tissues. In disease conditions, the expression of chemokine receptors, such as CCR4 and CCR8, on $T_{\text {reg }}$ cells allows their migration and recruitment to the site of inflammation [46]. In several human diseases, $\mathrm{T}_{\text {reg }}$ cells preferentially accumulate at lymphoid tissues or sites of affected organs $[47,48]$. Therefore, it is possible that decreases in peripheral $\mathrm{T}_{\text {reg }}$ cells in CHF patients are caused by $\mathrm{T}_{\text {reg-cell }}$ reallocation rather than an overall decrease. To investigate this possibility, we compared the $\mathrm{T}_{\text {reg-cell numbers in the mediastinal }}$ lymph nodes or Foxp3 expression in cardiac biopsies between CHF patients and non-CHF controls. The results revealed that

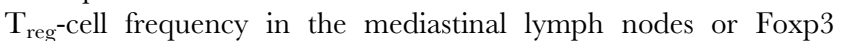
expression in hearts of $\mathrm{CHF}$ patients was no higher than that of the non-CHF controls. However, this possibility could not be excluded due to the very small sample number. In addition to generation in the thymus, $\mathrm{T}_{\text {reg }}$ cells can also be converted from activated effector or memory $\mathrm{CD} 4^{+} \mathrm{CD} 25^{-} \mathrm{T}$ cells in the periphery [49]. Peripherally converted $\mathrm{T}_{\text {reg }}$ cells and thymusgenerated $\mathrm{T}_{\text {reg }}$ cells demonstrate a similar phenotype and suppressive functions. It is possible that such peripheral T-cell phenotype conversion was altered in CHF patients. This hypothesis merits further investigation.

$\mathrm{TNF}-\alpha$ is central in the inflammatory cytokines response in $\mathrm{CHF}$ and play a role in the pathogenesis and clinical progression of the disease [50]. IL-10, an anti-inflammatory cytokine, may offer protection against TNF- $\alpha$ and an improvement in cardiac function in CHF has been associated with an increase in IL-10 [51] or a decrease in TNF- $\alpha / \mathrm{IL}-10$ ratio [52]. Our data indicated that $\mathrm{T}_{\text {reg }}$ frequency was negatively correlated with serum level of TNF- $\alpha$ or the TNF- $\alpha /$ IL-10 ratio (Figure S1). In both our previous study [17] and the present study, we observed that total $\mathrm{T}_{\text {reg }}$ number was significantly negatively correlated NT-proBNP which is considered as the most sensitive index of cardiac dysfunction in CHF patients. Based on these observations, we may speculate that $T_{\text {reg }}$ cells provided protection for the failing 
a

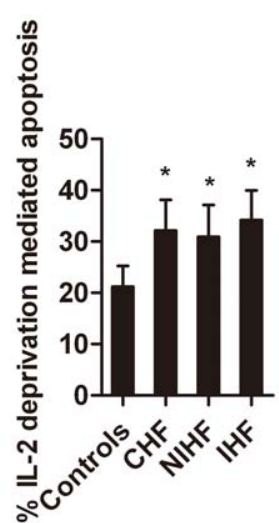

$c$

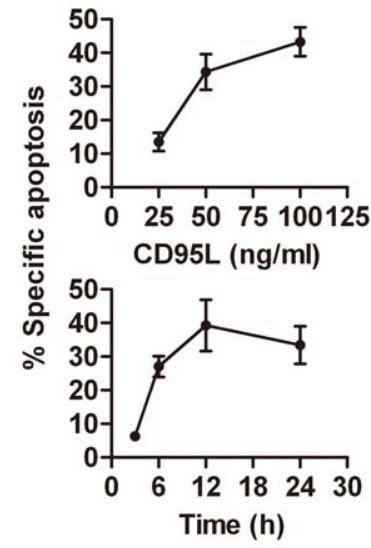

b
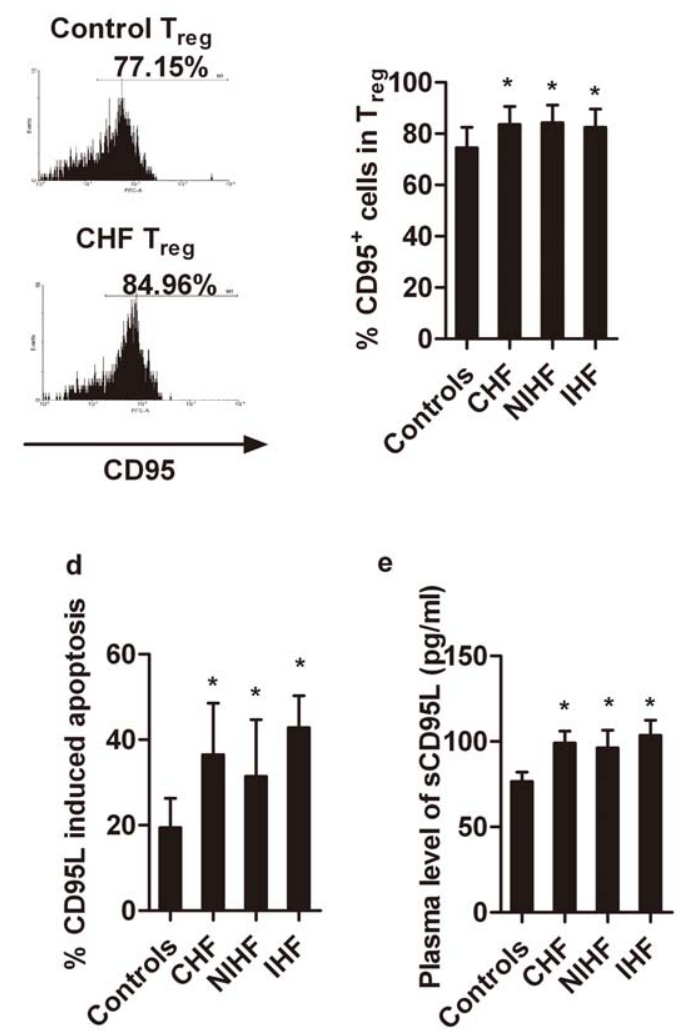

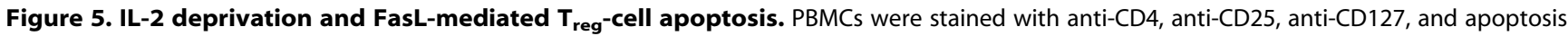

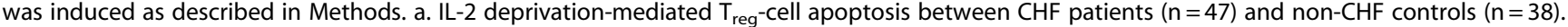
b. CD95 expression on gated $T_{\text {reg }}$ cells from CHF patients $(n=47)$ and non-CHF controls $(n=38)$. c. CD95L induced a dose-dependent apoptosis of $T_{\text {reg }}$ cells from CHF patients after incubation with CD95L for $12 \mathrm{~h}$ (upper panel; data are means from three separate experiments). Apoptosis of $\mathrm{T}_{\text {reg }}$ cells from CHF patients in the presence of $100 \mathrm{ng} / \mathrm{ml} \mathrm{CD95L}$ was plotted against time (lower panel; data are means from three separate experiments). d. FasL-induced apoptosis of $\mathrm{T}_{\text {reg }}$ cells from CHF patients and non-CHF controls ( $100 \mathrm{ng} / \mathrm{ml}$ FasL for 12 hrs). e. ELISA determination of plasma soluble FasL levels in 47 CHF patients and 38 non-CHF controls. ${ }^{*} p<0.05$ vs. non-CHF controls. doi:10.1371/journal.pone.0024272.g005

heart and defects in $\mathrm{T}_{\text {reg }}$ cells is involved in the deterioration of cardiac function in $\mathrm{CHF}$ patients. However, the direct effect of $\mathrm{T}_{\text {reg }}$ cells on cardiac dysfunction still needs to be studied in animal model.

IL-10 and TGF- $\beta 1$ have been identified as the main effector cytokines of $\mathrm{T}_{\text {reg }}$ cells [53]. We investigated the hypothesis that impaired $\mathrm{T}_{\text {reg-cell function was associated with the decreased }}$ expression of these two cytokines. Disappointedly, we failed to observe a decrease in the expression of either IL-10 or TGF- $\beta 1$ in CHF patients (Figure S2).

To conclude, our study revealed that both impaired export from the thymus and enhanced apoptosis can account for impaired

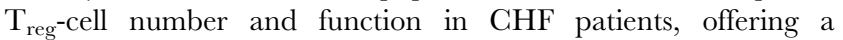
mechanistic explanation for the phenotypes and providing possible novel targets for CHF therapy through $\mathrm{T}_{\text {reg }}$-cell manipulation.

\section{Materials and Methods}

\section{Subjects}

samples were collected from $52 \mathrm{CHF}$ patients (31 men and 21 women, $44 \pm 13$ years old) and 43 non-CHF controls (28 men and 15 women, $42 \pm 12$ years old). Peripheral blood mononuclear cells (PBMCs) were prepared by Ficoll density gradient centrifugation
(Sigma, USA). Plasma was obtained after centrifugation and stored at $-80^{\circ} \mathrm{C}$. CHF diagnoses were based on clinical history, physical examination, echocardiography, chest X-ray, electrocardiography and levels of N-terminal pro-brain natriuretic peptide (NTproBNP), according to available guidelines pertaining to $\mathrm{CHF}$. Patients were classified as having non-ischemic heart failure (NIHF) ( $\mathrm{n}=32,17$ men and 15 women) if they had no history of myocardial infarction and did not have significant coronary artery stenosis upon coronary angiography. Patients were considered to have ischemic heart failure (IHF) $(\mathrm{n}=20,14$ men and 6 women) if the coronary angiography presented significant coronary artery disease $(>50 \%$ stenosis in more than one major epicardial coronary artery) or the patients had a history of myocardial infarction or previous revascularization. Patients were excluded (1) if they were currently treated with anti-inflammatory drugs, such as non-steroidal anti-inflammatory drugs and steroids, (2) if they had collagen disease, thromboembolism, disseminated intravascular coagulation, advanced liver disease, renal failure, malignant disease, other inflammatory disease (such as septicemia, pneumonia), valvular heart disease, or atrial fibrillation, or (3) if they had pacemakers. Patients with higher serum cholesterol than the target values after risk stratification [54], who received statin therapy within 3 months, were also excluded. Mediastinal lymph nodes 
a

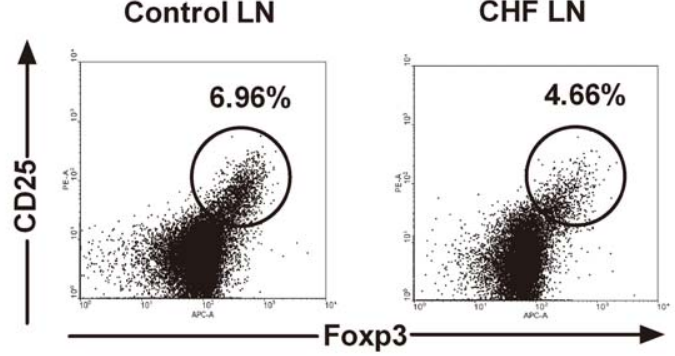

b

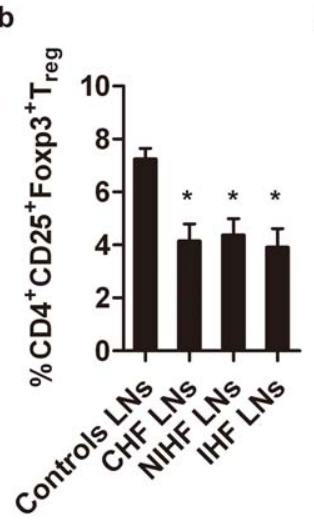

C

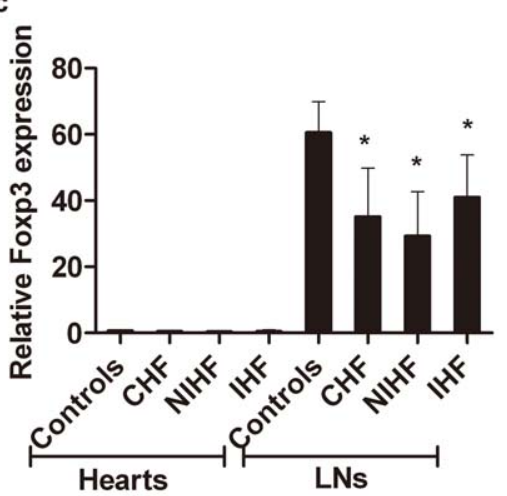

Figure 6. $T_{\text {reg }}$ cells in mediastinal lymph nodes and hearts. a. Representative FACS dot plots showed the presence of $\mathrm{CD}^{+} \mathrm{CD} 25^{+} \mathrm{Foxp}^{+} \mathrm{T}_{\text {reg }}$ cells in the mediastinal lymph nodes. $\mathrm{b}$. Percentages of $\mathrm{CD}^{+} \mathrm{CD} 25^{+} \mathrm{Foxp}^{+} \mathrm{T}_{\text {reg }}$ cells in the mediastinal lymph nodes were determined in six CHF patients (three with idiopathic cardiomyopathy and three with ischemic cardiomyopathy) and three controls without cardiomyopathy. c. Comparison of Foxp3 expression in the mediastinal lymph nodes and hearts of $\mathrm{CHF}$ and non-CHF controls. ${ }^{*} p<0.05$ vs. non-CHF controls.

doi:10.1371/journal.pone.0024272.g006

[55] and left ventricular biopsies were obtained from six $\mathrm{CHF}$ patients (three patients with dilated cardiomyopathy who underwent cardiac transplantation and three patients with coronary heart disease who underwent the combined bypass surgery and left ventricular aneurysm resection) and three controls (heart graft donors without cardiomyopathy who died in car accidents).

\section{Ethics statement}

The investigation conforms to the principles outlined in the Declaration of Helsinki. The trial was approved by the ethics committee of Tongji Medical College of Huazhong University of Science and Technology and patients and controls provided written informed consent.

\section{Naïve $T_{\text {reg }}\left(n T_{\text {reg }}\right)$, memory $T_{\text {reg }}\left(m T_{\text {reg }}\right)$ and recent} thymic emigrant- $T_{\text {reg }}\left(R T E-T_{\text {reg }}\right)$ cells in the circulation

A 6-color flow cytometry analysis was performed to determine levels of $\mathrm{nT}_{\text {reg }}, \mathrm{mT}_{\text {reg }}$ and $\mathrm{RTE}-\mathrm{T}_{\text {reg }}$ in the circulation. PBMCs were stained with surface antibodies for APC/Cy7 anti-human CD4, PE anti-human CD25, FITC anti-human CD45RA, Percp/ Cy5.5 anti-human CD45RO and PE/Cy7 anti-human CD31 (Biolegend) for $30 \mathrm{~min}$ at $4^{\circ} \mathrm{C}$. After surface staining, cells were fixed, permeabilized, and stained with APG anti-human Foxp3, according to the manufacturer's instructions (eBioscience, USA). Antibody isotype controls were performed to ensure antibody specificity. Stained cells were analyzed by flow cytometry with FACS Aria (BD Biosciences, USA).

\section{4. $T_{\text {reg }}$-cell isolation}

A two-step selection using a CD $4^{+} \mathrm{CD} 25^{+} \mathrm{CD} 127^{\mathrm{dim} /-}$ Regulatory $\mathrm{T}$ cell Isolation Kit (Miltenyi Biotec, Germany) was used to isolate $\mathrm{T}_{\text {reg }}$ cells according to the manufacturer's instructions. Briefly, non-CD $4^{+}$and CD $127^{\text {high }}$ cells were magnetically labeled with a cocktail of biotin-conjugated antibodies and anti-biotin microbeads and subsequently depleted by negative selection. Preenriched $\mathrm{CD}^{+}{ }^{+} \mathrm{T}$ cells were then labeled with anti-CD25 microbeads, and CD $4^{+} \mathrm{CD} 25^{+} \mathrm{CD} 127^{\mathrm{dim} /-} \mathrm{T}_{\text {reg }}$ cells were isolated by positive selection. FACS was used to confirm the purity $(>90 \%)$ of the isolated $\mathrm{T}_{\text {reg }}$ cells.

\section{Quantification of T-cell receptor excision circles (TRECs)}

The Wizard ${ }^{\circledR}$ Genomic DNA Purification Kit (Promega, USA) was used to extract genomic DNA (gDNA) from purified $\mathrm{T}_{\text {reg }}$ cells. Quantitative real-time PCR on an ABI Prism 7900 sequence detection system (Applied Biosystems, USA) was used to determine the number of TREGs. Primer pairs and probes were as follows:

TREC: F: 5'-aacagcctttgggacactatcg-3'， R: 5'-gctgaacttattgcaactcgtgag-3', probe: 5'-6FAM-ccacatccetttcaaccatgctgacacctcTAMAR-3';

RAG2: F: 5'-gcaacatgggaaatggaactg-3', R: 5'-ggtgtcaaattcatcatcaccatc-3', probe: 5'-6FAM-ccctggatcttctgttgatgttgactgttgtgaTRAMRA-3'. Data were expressed as TRECis $/ 10^{6}$ cells.

\section{Apoptosis assays}

Freshly isolated PBMCs were first stained with surface antibodies APC/Cy7 anti-human CD4, PE anti-human CD25, Percp/Cy5.5 anti-human CD95 (Fas) (Biolegend, USA) and Alexa Fluor ${ }^{\circledR} 647$ anti-human CD127 (eBioscience, USA). Cells with the phenotype $\mathrm{CD} 4^{+} \mathrm{CD} 25^{+} \mathrm{CD} 127^{\text {low }}$ were identified as $\mathrm{T}_{\text {reg }}$ cells. Apoptosis was measured using annexin $\mathrm{V}$ and 7-aminoactinomycin D (7-AAD) co-staining (Bender MedSystems, USA). The proportion of annexin $\mathrm{V}^{+} 7-\mathrm{AAD}^{-}$apoptotic cells in $7-\mathrm{AAD}^{-}$ viable $\mathrm{T}_{\text {reg }}$ cells and the surface expression of CD95 on $\mathrm{T}_{\text {reg }}$ cells were analyzed using FACS Aria (BD Biosciences, USA).

For IL-2 deprivation-mediated apoptosis, cells were stimulated with $2 \mu \mathrm{g} / \mathrm{ml}$ plate-bound anti-CD3 (eBioscience, USA) and antihuman IL-2 monoclonal antibodies (Peprotech, $2 \mu \mathrm{g} / \mathrm{ml}$ ) for 3 days. For Fas ligand (FasL)-induced apoptosis, cells were stimulated with gradient concentrations of soluble recombinant FasL (Peprotech, USA) in complete RPMI1640 containing IL-2 $(100 \mathrm{IU} / \mathrm{ml})$ for $12 \mathrm{hrs}[56]$. CD $4{ }^{+} \mathrm{CD} 25^{+} \mathrm{CD} 127^{\text {low } /-} \mathrm{T}_{\text {reg }}$ cells were also gated for annexin $\mathrm{V}^{+} 7-\mathrm{AAD}^{-}$to determine apoptotic cell populations. Cell death was presented as (Percent of IL-2 deprivation- or FasL-mediated apoptosis - percent of apoptosis in the absence of anti-human IL-2 or FasL) / (100\% - percent of cells in the absence of anti-human IL-2 or FasL $\times 100$.

\section{Soluble CD95 ligand (sCD95L) ELISA detection}

Human FasL/TNFSF6 Quantikine ELISA Kit (R\&D Systems, USA) was used to determine the plasma sCD95L levels. The minimal detectable concentration was $2.66 \mathrm{pg} / \mathrm{ml}$, and intra-assay and inter-assay coefficients of variation were $<10 \%$. All samples were measured in duplicate.

\section{8. $T_{\text {reg-cell detection in mediastinal lymph node }}$}

Mediastinal lymph nodes were minced and filtered through a cell strainer to create a single cell suspension preparation. Lymphocytes were isolated using Ficoll-Hypaque, stained with specific antibodies for CD4, CD25 and Foxp3, and subjected to FACS analysis. The number of $\mathrm{T}_{\text {reg }}$ cells in the lymph nodes was quantified by flow cytometry. 


\section{Real-time PCR}

Total RNA was extracted using Trizol lysis buffer (Invitrogen, USA), and cDNA was prepared using the Revertra Ace ${ }^{\circledR}$ kit (Toyobo, Japan). Expression of target genes (Bcl-2 and Bak in purified $\mathrm{T}_{\text {reg }}$ and Foxp3 cells) in heart tissues and lymphocytes isolated from mediastinal lymph nodes was quantified using the SYBR Green Master Mix (Takara, Japan) on an ABI Prism 7900 Sequence Detection system (Applied Biosystems, USA). Primer pairs were as follows:

Bcl-2: F, 5-tacctgaaccggcacctg-3, R, 5-gccgtacagttccacaaagg-3;

Bak: F, 5-cctgccctctgcttctgag-3, R, 5-ctgctgatggcggtaaaaa-3;

Foxp3: F, 5'-gaaacagcacattcccagagttc-3', R, 5'-atggcccagcggatgag- $3^{\prime}$

GAPDH: F，5'-ccacatcgctcagacaccat-3'， R， 5'-ggcaacaatatccactttaccagagt- $3^{\prime}$

For each sample, the mRNA expression level was normalized to that of GAPDH. The mean of duplicate measurements was normalized and expressed as a ratio of target mRNA copies to GAPDH mRNA copies.

10. Quantification of transforming growth factor (TGF)- $\alpha$ and interleukin (IL)-10 expression in $\mathrm{T}_{\text {reg }}$ cells

PBMCs were cultured in RPMI1640 containing 10\% FBS and stimulated with PMA (50ng/ml; Sigma-Aldrich, USA), ionomycin $(1 \mu \mathrm{g} / \mathrm{ml}$, Sigma-Aldrich, USA $)$ and monensin $(1 \mu \mathrm{M}$, eBioscience, USA) for $4 \mathrm{~h}$. Cells were stained with surface antibodies for APC/Cy7 anti-human CD4, PE anti-human CD25 (Biolegend, USA), Alexa Fluor ${ }^{\circledR} 647$ anti-human CD127 (ebioscience, USA) for $30 \mathrm{~min}$ at $4{ }^{\circ} \mathrm{C}$. After surface staining, cells were fixed, permeabilized, and stained with PE-cy7 anti-human TNF- $\alpha$ or PE-cy7 anti-human IL-10 (Biolegend, USA). Stained cells were analyzed by flow cytometry with FACS Aria (BD Biosciences, USA).

\section{Tumor necrosis factor (TNF)- $\alpha$ and IL-10 ELISA detection}

Commercial ELISA Kits (Invitrogen, USA) were used to determine the plasma TNF- $\alpha$ and IL-10 levels. The minimal detectable concentrations were $0.5 \mathrm{pg} / \mathrm{ml}$ and $0.78 \mathrm{pg} / \mathrm{ml}$ for

\section{References}

1. Yndestad A, Damås JK, Oie E, Ueland T, Gullestad L, et al. (2006) Systemic inflammation in heart failure-the whys and wherefores. Heart Fail Rev 11: 83-92.

2. Yndestad A, Holm AM, Müller F, Simonsen S, Frøland SS, et al. (2003) Enhanced expression of inflammatory cytokines and activation markers in Tcells from patients with chronic heart failure. Cardiovasc Res 60: 141-146.

3. Sakaguchi S, Ono M, Setoguchi R, Yagi H, Hori S, et al. (2006) Foxp3+ CD25+ $\mathrm{CD} 4+$ natural regulatory $\mathrm{T}$ cells in dominant self-tolerance and autoimmune disease. Immunol Rev 212: 8-27.

4. Mor A, Luboshits G, Planer D, Keren G, George J (2006) Altered status of CD4(+)CD25(+) regulatory $\mathrm{T}$ cells in patients with acute coronary syndromes. Eur Heart J 27: 2530-2537.

5. Cheng X, Yu X, Ding YJ, Fu QQ, Xie JJ, et al. (2008) The Th17/Treg imbalance in patients with acute coronary syndrome. Clin Immunol 127: 89-97.

6. Viglietta V, Baecher-Allan G, Weiner HL, Hafler DA (2004) Loss of functional suppression by CD4+CD25+ regulatory $\mathrm{T}$ cells in patients with multiple sclerosis. J Exp Med 971: 9-19.

7. Lindley S, Dayan CM, Bishop A, Roep BO, Peakman M, et al. (2005) Defective suppressor function in CD4(+)CD25(+) T-cells from patients with type 1 diabetes. Diabetes 54: 92-99.

8. Ehrenstein MR, Evans JG, Singh A, Moore S, Warnes G, et al. (2004) Compromised function of regulatory $\mathrm{T}$ cells in rheumatoid arthritis and reversal by anti-TNF alpha therapy. J Exp Med 200: 277-285.

9. Ait-Oufella H, Salomon BL, Potteaux S, Robertson AK, et al. (2006) Natural regulatory $\mathrm{T}$ cells control the development of atherosclerosis in mice. Nat Med 12: $178-180$.

10. Chen X, Fang L, Song S, Guo TB, Liu A, et al. (2009) Thymic regulation of autoimmune disease by accelerated differentiation of Foxp3+ regulatory $\mathrm{T}$ cells through IL-7 signaling pathway. J Immunol 183: 6135-44.
TNF- $\alpha$ and IL-10 respectively. All samples were measured in duplicate.

\section{Statistical analysis}

Values are expressed as means \pm standard deviation (SD) or percentage in the text and figures. For variables with normal distribution and homogeneity of variance, independent $t$-test or one-way analysis of variance (ANOVA) was used to test differences among two or more groups. For skewed variables, either nonparametric Kruskal-Wallis $\mathrm{H}$ test or Mann-Whitney $U$ test were used for analyses. For the ranked data, Pearson's chi-square test or Fisher's exact test were used for the comparison between multiple groups. Spearman's correlation analysis was performed to determine correlation between the variables. In all cases, twotailed, $p<0.05$ was considered significant.

\section{Supporting Information}

Figure $S 1$ Correlation analysis between $T_{\text {reg }}$ frequency and plasma levels of cytokines in CHF patients $(n=20)$. (TIF)

Figure S2 Comparison of intracellular IL-10 and TGF$\beta 1$ in $\mathrm{CD}^{+} \mathrm{CD}^{+} 5^{+} \mathrm{CD}_{127^{\text {low }}} \mathrm{T}_{\text {reg }}$ between $\mathrm{CHF}$ patients $(\mathbf{n}=10)$ and healthy controls $(n=10)$.

(TIF)

\section{Acknowledgments}

We thank Li Yangqiu for providing the TREC plasmid. We also thank all the patients who participated in this study.

\section{Author Contributions}

Conceived and designed the experiments: XC TTT ZFZ JW WCZ. Performed the experiments: XC TTT ZFZ JW WCZ HX XLD JHX NGD WS NX XXY SFN JL SFZ RY JJX HJ MYL. Analyzed the data: XG TTT ZFZ JW WCZ HX XLD JHX NGD WS NX XXY SFN JL SFZ RY JJX HJ MYL. Contributed reagents/materials/analysis tools: XC TTT ZFZ JW WCZ XT HX XLD JHX NGD WS NX XXY SFN JL SFZ RY JJX HJ MYL XW. Wrote the paper: XC TTT ZFZ JW WCZ. Critical revision of the manuscript and study supervision: YHL GPS MF.

11. Tang Q, Henriksen KJ, Bi M, Finger EB, Szot G, et al. (2004) In vitro-expanded antigen-specific regulatory $\mathrm{T}$ cells suppress autoimmune diabetes. J Exp Med 199: $1455-1465$.

12. Morgan ME, Flierman R, van Duivenvoorde LM, Witteveen HJ, van Ewijk W, et al. (2005) Effective treatment of collagen-induced arthritis by adoptive transfer of CD25+ regulatory T cells. Arthritis Rheum 52: 2212-2221.

13. Cohn JN, Ferrari R, Sharpe N (2000) Cardiac remodeling-concepts and clinical implications: a consensus paper from an international forum on cardiac remodeling. Behalf of an International Forum on Cardiac Remodeling. J Am Coll Cardiol 35: 569-82.

14. Frantz S, Bauersachs J, Ertl G (2009) Post-infarct remodelling: contribution of wound healing and inflammation. Cardiovasc Res 81: 474 481.

15. Dobaczewski M, Xia Y, Bujak M, Gonzalez-Quesada C, Frangogiannis NG (2010) CCR5 signaling suppresses inflammation and reduces adverse remodeling after myocardial infarction-mediated recruitment of regulatory $\mathrm{T}$ cells. Am J Pathol 176: 2177-2187.

16. Kvakan H, Kleinewietfeld M, Qadri F, Park JK, Fischer R, et al. (2009) Regulatory $\mathrm{T}$ cells ameliorate angiotensin II-induced cardiac damage. Circulation 119: 2904-2912.

17. Tang TT, Ding YJ, Liao YH, Yu X, Xiao H, et al. (2010) Defective circulating $\mathrm{CD} 4^{+} \mathrm{CD} 25^{+}$Foxp $3^{+} \mathrm{CD} 127^{\text {low }}$ regulatory T-cells in patients with chronic heart failure. Cell Physiol Biochem 25: 451-458.

18. Hazenberg MD, Verschuren MC, Hamann D, Miedema F, van Dongen JJ (2001) $\mathrm{T}$ cell receptor excision circles as markers for recent thymic emigrants: basic aspects, technical approach, and guidelines for interpretation. J Mol Med 79: 631-640.

19. Liu W, Putnam AL, Xu-Yu Z, Szot GL, Lee MR, et al. (2006) CD127 expression inversely correlates with FOXP3 and suppressive function of human CD4+ Treg cells. J Exp Med 203: 1701-1711. 
20. Nelson BH (2004) IL-2, regulatory T cells, and tolerance. J Immunol 172: 3983-3988.

21. Taams LS, Smith J, Rustin MH, Salmon M, Poulter LW, et al. (2001) Human anergic/suppressive CD4(+)CD25(+) T cells: a highly differentiated and apoptosis-prone population. Eur J Immunol 31: 1122-1131.

22. Krammer PH (2000) CD95's deadly mission in the immune system. Nature 407: 789-795.

23. Fritzsching B, Oberle N, Eberhardt N, Quick S, Haas J, et al. (2005) In contrast to effector T cells, CD4+CD25+FoxP3+ regulatory $\mathrm{T}$ cells are highly susceptible to CD95 ligand- but not to TCR-mediated cell death. J Immunol 175: 32-36.

24. Frangogiannis NG, Smith CW, Entman ML (2002) The inflammatory response in myocardial infarction. Cardiovasc Res 53: 31-47.

25. Mason JW (2003) Myocarditis and dilated cardiomyopathy: an inflammatory link. Cardiovasc Res 60: 5-10.

26. Caforio AL, Tona F, Bottaro S, Vinci A, Dequal G, et al. (2008) Clinical implications of anti-heart autoantibodies in myocarditis and dilated cardiomy opathy. Autoimmunity 41: 35-45.

27. Teplliakov AT, Bolotskaia LA, Dibirov MM, Stepacheva TA, et al. (2008) Clinicoimmunological disorders in patients with postinfarction left ventricular remodeling and chronic cardiac failure. Ter Arkh 80: 52-57.

28. Düngen HD, Platzeck M, Vollert J, Searle J, Müller C, et al. (2010) Autoantibodies against cardiac troponin I in patients with congestive heart failure. Eur J Heart Fail 12: 668-675.

29. Deubner N, Berliner D, Schlipp A, Gelbrich G, Caforio AL, et al. (2010) Etiology, Titre-Course, and Survival-Study Group. Cardiac betal-adrenoceptor autoantibodies in human heart disease: rationale and design of the Etiology, Titre-Course, and Survival (ETiCS) Study. Eur J Heart Fail 12: 753-762.

30. Omerovic E, Bollano E, Andersson B, Kujacic V, Schulze W, et al. (2000) Induction of cardiomyopathy in severe combined immunodeficiency mice by transfer of lymphocytes from patients with idiopathic dilated cardiomyopathy. Autoimmunity 32: 271-280.

31. Varda-Bloom N, Leor J, Ohad DG, Hasin Y, Amar M, et al. (2000) Cytotoxic T lymphocytes are activated following myocardial infarction and can recognize and kill healthy myocytes in vitro. J Mol Cell Cardiol 32: 2141-2149.

32. Maisel A, Cesario D, Baird S, Rehman J, Haghighi P, et al. (1998) Experimental autoimmune myocarditis produced by adoptive transfer of splenocytes after myocardial infarction. Circ Res 82: 458-463.

33. Josefowicz SZ, Rudensky A (2009) Control of regulatory T cell lineage commitment and maintenance. Immunity 30: 616-625.

34. Valmori D, Merlo A, Souleimanian NE, Hesdorffer CS, Ayyoub M (2005) A peripheral circulating compartment of natural naive CD4 Tregs. J Clin Invest 115: 1953-1962

35. Vukmanovic-Stejic M, Zhang Y, Cook JE, Fletcher JM, McQuaid A, et al. (2006) Human CD4+ CD25hi Foxp3+ regulatory T cells are derived by rapid turnover of memory populations in vivo. J Clin Invest 116: 2423-2433.

36. Gregg R, Smith CM, Clark FJ, Dunnion D, Khan N, et al. (2005) The number of human peripheral blood CD4+ CD25high regulatory $\mathrm{T}$ cells increases with age. Clin Exp Immunol 140: 540-546.

37. Akbar AN, Vukmanovic-Stejic M, Taams LS, Macallan DC (2007) The dynamic co-evolution of memory and regulatory CD4+ T cells in the periphery. Nat Rev Immunol 7: 231-7.

38. Haas J, Fritzsching B, Trübswetter P, Korporal M, Milkova L, et al. (2007) Prevalence of newly generated naïve regulatory T cells (Treg) is critical for Treg suppressive function and determines Treg dysfunction in multiple sclerosis. J Immunol 179: 1322-1330.
39. Venken K, Hellings N, Broekmans T, Hensen K, Rummens JL, et al. (2008) Natural naive CD4+CD25+CD127low regulatory T cell (Treg) development and function are disturbed in multiple sclerosis patients: recovery of memory Treg homeostasis during disease progression. J Immunol 180: 6411-6420.

40. Nakano A, Watanabe M, Iida T, Kuroda S, Matsuzuka F, et al. (2007) Apoptosis-induced decrease of intrathyroidal CD4(+)CD25(+) regulatory T cells in autoimmune thyroid diseases. Thyroid 17: 25-31.

41. Stanzer S, Dandachi N, Balic M, Resel M, Samonigg H, et al. (2008) Resistance to apoptosis and expansion of regulatory $\mathrm{T}$ cells in relation to the detection of circulating tumor cells in patients with metastatic epithelial cancer. J Clin Immunol 28: 107-114.

42. Fritzsching B, Korporal M, Haas J, Krammer PH, Suri-Payer E, et al. (2006) Similar sensitivity of regulatory T cells towards CD95L-mediated apoptosis in patients with multiple sclerosis and healthy individuals. J Neurol Sci 251: 91-97.

43. Glisic-Milosavljevic S, Waukau J, Jailwala P, Jana S, Khoo HJ, et al. (2007) Atrisk and recent-onset type 1 diabetic subjects have increased apoptosis in the CD4+CD25+ T-cell fraction. PLoS One 2: e146.

44. Xu G, Shi Y (2007) Apoptosis signaling pathways and lymphocyte homeostasis. Cell Res 17: 759-771.

45. Yamaguchi S, Yamaoka M, Okuyama M, Nitoube J, Fukui A, et al. (1999) Elevated circulating levels and cardiac secretion of soluble Fas ligand in patients with congestive heart failure. Am J Cardiol 83: 1500-1503.

46. Wei S, Kryczek I, Zou W (2006) Regulatory T-cell compartmentalization and trafficking. Blood 108: 426-431.

47. Hesse M, Piccirillo CA, Belkaid Y, Prufer J, Mentink-Kane M, et al. (2004) The pathogenesis of schistosomiasis is controlled by cooperating IL-10-producing innate effector and regulatory T cells. J Immunol 172: 3157-3166.

48. Suvas S, Azkur AK, Kim BS, Kumaraguru U, Rouse BT (2004) CD4+CD25+ regulatory $\mathrm{T}$ cells control the severity of viral immunoinflammatory lesions. J Immunol 172: 4123-4132.

49. Liang S, Alard P, Zhao Y, Parnell S, Clark SL, et al. (2005) Conversion of CD4+ CD25- cells into CD4+ CD25+ regulatory $\mathrm{T}$ cells in vivo requires $\mathrm{B} 7$ costimulation, but not the thymus. J Exp Med 201: 127-137.

50. Kleinbongard P, Schulz R, Heusch G (2011) TNF $\alpha$ in myocardial ischemia/ reperfusion, remodeling and heart failure. Heart Fail Rev 16(1): 49-69.

51. Adamopoulos S, Parissis JT, Paraskevaidis I, et al. (2003) Effects of growth hormone on circulating cytokine network, and left ventricular contractile performance and geometry in patients with idiopathic dilated cardiomyopathy. Eur Heart J 24(24): 2186-96.

52. Stumpf C, Lehner C, Yilmaz A, Daniel WG, Garlichs CD (2003) Decrease of serum levels of the anti-inflammatory cytokine interleukin-10 in patients with advanced chronic heart failure. Clin Sci (Lond) 105(1): 45-50.

53. Askenasy N, Kaminitz A, Yarkoni S (2008) Mechanisms of T regulatory cell function. Autoimmun Rev 7(5): 370-5.

54. Joint committee for developing Chinese guidelines on prevention and treatment of dyslipidemia in adults (2007) Chinese guidelines on prevention and treatment of dyslipidemia in adults. Chin J Cardiol 35: 390-419.

55. Luppi P, Rudert WA, Zanone MM, Stassi G, Trucco G, et al. (1998) Idiopathic dilated cardiomyopathy: a superantigen-driven autoimmune disease. Circulation 98: 777-785.

56. Miyara M, Amoura Z, Parizot G, Badoual C, Dorgham K, et al. (2005) Global natural regulatory $\mathrm{T}$ cell depletion in active systemic lupus erythematosus. J Immunol 175: 8392-8400. 